\title{
Adverse Childhood Experiences (ACEs) and Timely Bachelor's Degree Attainment ${ }^{\dagger}$
}

\section{Carolina Otero}

\section{check for}

updates

Citation: Otero, Carolina. 2021. Adverse Childhood Experiences (ACEs) and Timely Bachelor's Degree Attainment. Social Sciences 10: 44. https://doi.org/10.3390/ socsci10020044

Academic Editor: Ben Gibbs Received: 1 November 2020 Accepted: 9 December 2020 Published: 27 January 2021

Publisher's Note: MDPI stays neutral with regard to jurisdictional claims in published maps and institutional affiliations.

Copyright: (C) 2021 by the author. Licensee MDPI, Basel, Switzerland. This article is an open access article distributed under the terms and conditions of the Creative Commons Attribution (CC BY) license (https:/ / creativecommons.org/licenses/by/ $4.0 /)$.
Department of Sociology, University of Southern California, Los Angeles, CA 90007, USA; oterocar@usc.edu + Note: This paper was developed from the author's master thesis and a version of it was previously presented at the 2017 American Sociological Association Annual Meeting in Montréal, Québec, Canada.

\begin{abstract}
It is well established that adverse childhood experiences (ACEs) are linked to health and emotional outcomes. However, less is known about the relationship between ACEs and educational attainment-a potentially important feature of educational stratification in America. Using the National Longitudinal Study of Adolescent to Adult Health (Add Health), a nationally representative study following 7-12th grade students in the 1994-95 school year, I investigate the link between ACEs and these students' timely post-secondary attainment. I also explore the role of health and socioemotional factors as mediators. Results confirm that there is a graded relationship between ACEs and timely bachelor's degree attainment—an additional ACE decreases the odds of timely bachelor's degree attainment by about $17 \%$, even after accounting for other related factors. In addition, the findings suggest that general health partially mediates this link.
\end{abstract}

Keywords: ACEs; timely bachelor's degree attainment; physical health; socio-emotional well-being

\section{Introduction}

With good reason, traditional sociological explanations of educational attainment and achievement have focused on the role of ascription such as age, gender, and race in generating inequality (Grusky and Weisshaar 2014), and it has long been recognized that social-psychological factors likely influence the gap in educational outcomes (Sewell et al. 1969). While scholars find evidence for the link between social-psychological factors and educational attainment yet limited studies have examined the cumulative impact of several of these factors on educational attainment (Fletcher 2008, 2010; Needham 2009). Relatedly, the ecobiodevelopmental framework points to early traumatic childhood experiences - exposure to toxic stress - as fundamentally changing neurobiological processes that impact child development and other life outcomes (Danese and McEwen 2012; Shonkoff 2012; Shonkoff et al. 2009).

One such lens from which to study cumulative impact of childhood and socialpsychological factors is ACEs-a scale measuring exposure to negative child experiences from birth to about age 18 including abuse, neglect, and dysfunctional home environments. While several studies in the cumulative risk literature have studied the impact of child adversity on multiple outcomes including academic achievement and educational attainment (Swanson et al. 2012), child adversity has been only broadly defined in the cumulative risk literature (Evans et al. 2013). By contrast, the ACEs scale in the Centers for Disease Control and Prevention (CDC) use in-home experiences and family member-like relationships to analyze the cumulative impact of early adverse experiences on life outcomes. Exploring the role that ACEs has to educational attainment highlights the significance of non-school factors in educational attainment and contributes to how virtual in-home learning during the COVID-19 pandemic might impact student learning when children are experiencing adversity at home.

A conceptual contribution of the ACE measure is its additive approach to conventional measures of disadvantage in childhood. The combination of the negative experiences is 
thought to be more detrimental than isolated incidences. This measure includes ten categories which are each highly correlated in the literature (Dong et al. 2004) and are stable and statistically reliable over time (Dube et al. 2004). The ACEs research generally finds a "dose-response" or cumulative effect of an additional ACE on outcomes such as physical health, chronic depression, and psychological well-being (Chartier et al. 2010; Nurius et al. 2015; Steele et al. 2016).

To date, research examining the impact of ACEs on educational outcomes often focuses on academic performance (e.g., grade point average repeating a grade, language and literacy skills, math skills, etc.) and school engagement (Bethell et al. 2014; Jimenez et al. 2016) and are often limited to outcomes in adolescence (Giovanelli et al. 2016; Morrow and Villodas 2018). This study will explore the potential role of ACEs for timely bachelor's degree attainment in early adulthood and likely mediators of this relationship.

\section{The Background Literature}

\subsection{ACEs and Cumulative Effects}

Adverse Childhood Experiences (ACEs) is a cumulative measure of negative, traumatic experiences that have occurred during childhood. It was first introduced by Kaiser Permanente in the late 90s (Dube et al. 2001; Felitti et al. 1998; Mersky et al. 2013; Monnat and Chandler 2015). The 10-category ACEs scale is a component of a larger piece of literature that examines the effect of multiple risk factors or cumulative risk on social outcomes and their impact across the life course (Felitti et al. 1998). The scale includes measures on emotional, physical and sexual abuse; emotional neglect; physical neglect; parental separation or divorce; experiences of domestic violence of the mother; household substance abuse; mental illness present in the household; and criminal involvement by a household member (see Appendix A for further information). Research looking at ACEs has repeatedly found a cumulative effect of each additional adverse experience. And because adverse experiences are likely to co-occur, Study of single adversity measures likely miss other cumulative and co-occurring trauma (Dong et al. 2004; Felitti et al. 1998; Kessler et al. 1997; Lamers-Winkelman et al. 2012; McLaughlin et al. 2012). For example, Mersky et al. (2013) and Felitti et al. (1998) found that there is a graded relationship between exposure to ACEs and health and mental health outcomes in early adulthood and beyond-traumatic experiences are not isolated events but co-occur with others (Dong et al. 2004; Felitti et al. 1998). Thus, even though it is well documented that adverse experiences such as parental suicide, child abuse and neglect, parental incarceration, and parental substance abuse disrupt educational trajectories on their own, there is a critical cumulative effect when these factors co-occur.

To date, this important approach has been largely been applied to adolescent and adult health outcomes (see Anda et al. 2006; Chartier et al. 2010). However, ACEs affect other outcomes beyond physical health and well-being. Anda et al. (2006) found a graded relationship between ACEs and early intercourse, promiscuity, sexual dissatisfaction, anger management, and substance use and abuse, even after controlling for age, sex, and educational attainment. In addition, Anda et al. (2004) found a graded relationship between ACEs and adult worker performance, finding that participants with higher ACEs scores are more likely to report job and financial problems. Scholars have also explored the impact of ACEs and unemployment among adults in the U.S. Liu et al. (2013) found that compared to individuals with no ACEs, individuals with one or more ACE are at an increased risk of unemployment.

As some research has begun to examine the link between ACEs and educational outcomes, such as academic performance and educational attainment, no known ACE study has used nationally representative, longitudinal data to examine this link. I conceptualize the link between ACEs and educational attainment in Figure 1. The literature review will cover each of the links proposed in the model. First, I review what we know about ACEs and educational attainment. Then, I present potential mediating factors of the link—specifically socio-emotional well-being (depression) and general health. 


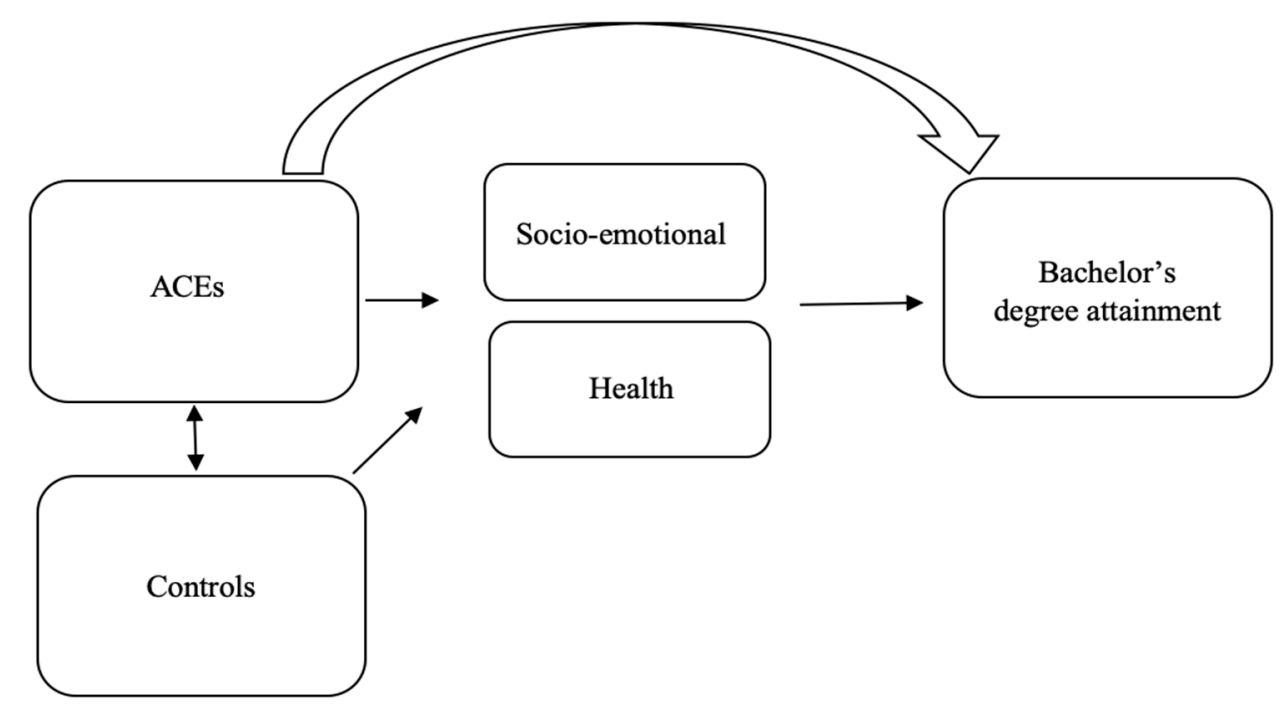

Figure 1. Conceptual Model. ACEs: adverse childhood experiences.

\subsection{ACEs and Educational Outcomes}

Research has found that academic achievement is linked to educational attainment, as educational attainment reflects the ability to excel academically and accumulate knowledge over time (Balfanz et al. 2007; Morrow and Villodas 2018). Bethell et al. (2014) found that there is lower school engagement among U.S. children with exposure to adverse childhood experiences. Other studies have also found associations between ACEs and below-average academic performance in math and literacy skill development in early childhood (Jimenez et al. 2016). ACE studies looking into academic performance suggest that ACEs also adversely influence educational attainment, as do other research studies on cumulative risk, which have found a relationship between exposure to a greater number of childhood risk factors and fewer years of education (Horan and Widom 2015).

Morrow and Villodas (2018) examined the cumulative effect of ACEs on the likelihood of dropping out of high school and found that an additional ACE increases the odds of dropping out of high school by $9 \%$. They found that ACEs directly and indirectly affect high school dropout rates. Factors such as reading achievement (age 16) and internalizing and externalizing behavior problems appear to mediate the relationship between ACEs and dropping out of high school.

One important study, similar to ours, found that participants with ACEs were worse off compared to participants that did not experience any ACEs in early adulthood-as the number of ACEs increased, the odds of high school graduation decreased, (Giovanelli et al. 2016). Giovanelli et al. also found increased risk for depression, juvenile arrest, and individuals are less likely to hold a skilled job in young adulthood (2016). Overall, individuals with high ACE scores completed fewer years of education-about half a year of education less compared to individuals with lower ACE scores. Moreover, no significant relationship existed with college attendance at a 4-year college; however, the authors hypothesized that this may have been due to the small percentage of college-goers in the sample (Giovanelli et al. 2016).

As important as these findings are for the research question, Giovanelli et al. (2016) only examined a low-income, urban cohort in Chicago. Likewise, Dube et al. (2010), find that individuals exposed to child adversities are more likely to obtain a lower level of education, but use only state survey data (2002 Texas Behavioral Risk Factor Surveillance System). While studies have found that growing evidence for an ACEs/educational link, I provide a national assessment of this link and its potential mediators. 


\subsection{ACEs, Socio-Emotional Well-Being, Health, and Educational Attainment}

Past research has linked ACEs to adult psychological well-being and substance abuse in young adulthood through various mechanisms such as stress and socio-emotional wellbeing. For instance, ACE research investigating dropping out of high school has found that reading achievement and externalizing problems are pathways through which ACEs are linked to dropping out of high school (Douglas et al. 2010; Morrow and Villodas 2018; Nurius et al. 2015). Less is known about the pathway through which ACEs may be operating in connection with educational attainment or if ACEs directly affect college attainment.

\subsubsection{ACEs and Socio-Emotional Well-Being}

ACEs are associated with socio-emotional well-being. Socio-emotional well-being are often related to social skills, such as the "ability to competently meet the demands of one's social environment, and psychological well-being, which includes feelings of self-worth, mastery, and purpose" (Hurd et al. 2013, p. 583). Studies have found that the additive component of adverse experiences impacts suicide attempt, depression, and psychological well-being among children and adolescents (Anda et al. 2006; Anderson et al. 2002; Chapman et al. 2004; Nurius et al. 2015; Turner et al. 2006; Youssef et al. 2017). However, other research has found mixed support for this link (Lamers-Winkelman et al. 2012). Lamers-Winkelman et al. (2012) found a link between the number of ACEs and adolescent trauma when reported by the parent but not when it was self-reported by the child or adolescent; in addition, there was no direct link found between ACEs and emotional or behavioral problems. However, their sample consisted of children referred to social welfare institutions whose primary caregivers were victims of intimate partner violence (IPV), and therefore may not be representative of the influence of ACEs on socioemotional outcomes more generally (Lamers-Winkelman et al. 2012). The authors also found that the children had high levels of adjustment problems compared to the average adjustment problems found in the population, suggesting that these ACE findings may not be nationally representative. Other scholars have found that ACEs are directly associated with panic reactions, depressive symptoms, anxiety and hallucinations, and being at risk for depressive disorders in adulthood (Anda et al. 2006; Chapman et al. 2004).

Moreover, recent research also signals mixed support for the relationship between ACEs and socio-emotional well-being. McLaughlin et al. (2012) found no cumulative ACE effect on the first onset of psychiatric disorders among a sample of adolescents. Conversely, Nurius et al. (2015) found that the ACE score significantly and uniquely impacts perceived well-being, psychological distress, and missed days of work/activities due to mental health conditions or emotional problems, even after controlling for other predictors.

Font and Maguire-Jack (2016) also found links between ACEs and being diagnosed with a depressive disorder, among other negative outcomes. Taken together, evidence of the $\mathrm{ACE} /$ socio-emotional well-being link is plausible but uncertain.

\subsubsection{Socio-Emotional Well-Being and Educational Attainment}

The association between socio-emotional well-being and educational attainment is clearer. Studies have found that emotional well-being is associated with educational attainment (Fletcher 2008, 2010). For example, using the Add Health, Needham (2009) found that depressive symptomatology in adolescence is associated with increased odds of dropping out of high school and decreased odds of enrolling in college. Depression is also associated with a decreased likelihood of enrolling at a 4-year college (but not a 2-year college) (Fletcher 2008). Fletcher (2010) found that a standard deviation increase in depressive symptoms, increases the likelihood of dropping out of college by $25-30 \%$, given high school completion. Research conducted by Hunt et al. (2010) also found that some mental health disorders such as bipolar disorder, antisocial personality disorder, and other substance abuse disorders influence college completion, but major depression did not, after introducing sociodemographic and family structure variables. 
In addition, research on mental health and academic achievement lends further support that mental health also affects educational attainment. For instance, mental health problems are associated with a greater likelihood of failing one or more classes the following school year (Needham et al. 2004). Needham et al. (2004) found that despite partial mediation by absenteeism, trouble with homework, individual-level teacher attachment, and emotional distress continued to be associated with academic failure, albeit marginally significant. McLeod et al. (2012) examined multiple indicators of mental health problems and found that attention problems are significantly associated with high school GPA, while depression was no longer significant in the full model.

\subsubsection{ACEs and Health}

There is strong support for the link between ACEs and an array of health outcomes across the life span (Anda et al. 2006; Bethell et al. 2014; Felitti et al. 1998; Larkin et al. 2012; Tietjen et al. 2012). For example, ACEs are linked to long-term health and the likelihood of reporting having fair or poor health (Chartier et al. 2010; Dube et al. 2010; Gilbert et al. 2015). Flaherty et al. (2013) found that exposure to numerous ACEs uniquely predicted poor health and having any health problem at age 14. Much of the ACEs literature has also explored the impact of ACEs on specific health conditions and diseases.

For instance, Dong et al. (2004) found that even though psychological factors and others substantially mediate the relationship between ACEs and the risk for heart disease, the direct relationship persists. Font and Maguire-Jack (2016) found a graded relationship between ACEs and obesity. Other studies found that ACEs are linked to biological changes that affect long-term outcomes such as aging and health (Danese and McEwen 2012). Brown et al. (2010) found a marginal direct link between ACEs and lung cancer even after controlling for smoking in the analysis. ACEs have also been linked to having trouble falling asleep or remaining asleep in adulthood, which are known to lead to chronic diseases and additional unhealthy behaviors (Chapman et al. 2011).

\subsubsection{Health and Educational Attainment}

As Figure 1 highlights, the pathway between ACEs and educational attainment may operate through an individual's physical health. A majority of the research looking at health and education has narrowed in on the link between education on adult health and life trajectory. Economists have studied how education positively influences a variety of outcomes including health and life quality (Eide and Showalter 2011; Johnson et al. 2016). Far fewer studies focus on the impact of health on educational attainment. Generally, scholars find evidence suggesting that health does influence educational attainment (Needham et al. 2004). For example, we know that childhood and adolescent health impacts academic performance (Eide and Showalter 2011). In addition, Sabia (2007) found that among 14-17 years old, a higher BMI leads to a lower GPA. Using the National Longitudinal Survey of Adolescent Health, Rees and Sabia (2011) found associations between migraines and high school GPA, high school graduation, and college attendance. Fletcher (2011) found that low birth weight leads to several adverse educational outcomes including a higher probability for early grade retention, usage of special education services, and a greater likelihood to report a learning disability. Additionally, research by Maslow et al. (2011) found that chronic illness impacts an array of social outcomes including marriage, having children, living with parents, lower mean income, and lower odds of college graduation.

\subsection{Moving Forward}

The current literature suggests growing evidence for the link between ACEs and educational attainment. However, to date, scholars have not utilized a national representative longitudinal study to examine this relationship. Therefore, I investigate the relationship between ACEs and timely bachelor's degree attainment and model the potential mediating role of general health and socio-emotional well-being. 


\section{Methods}

\subsection{Data and Sample}

Data for this study came from the National Longitudinal Survey of Adolescent Health (Add Health), an ongoing nationally representative study that first sampled 90,000 U.S. adolescents in grades 7-12 during the 1994-1995 school year. The Add Health collects data on social, economic, physical, behavioral, and psychological life aspects to study how context matters for young adulthood outcomes. The sampling design consisted of a multistage, stratified, school-based, cluster design of 132 middle and high schools across the U.S. (Chen and Chantala 2014). A stratified sample of 80 high schools were selected from a list of schools having at least an 11th grade and a minimum of 30 students enrolled. Feeder middle schools were also included. These high schools were found to be representative in terms of region, urbanity, size, school type, and ethnicity. Nearly all participating schools hosted an in-school questionnaire. For the in-home sample, researchers selected students at random. All students named on the school roster, regardless of whether they completed an in-school questionnaire or not, were eligible for selection into the in-home sample.

I use data from waves I, III and IV. Wave I of the in-home interview was collected between April and December 1995, when participants were 11 to 19 years of age $(n=20,745)$ (Chen and Chantala 2014). A parent, in most cases the mother, and a school administrator were also interviewed in Wave I. A year later, Wave II in-home data were collected between April and August 1996 with approximately 15,000 respondents. Researchers did not interview students that were in 12th grade in Wave I in the follow-up in Wave II. Wave III data were collected between August 2001 and April 2002, when respondents were between 18 and 26 years old $(n=15,100)$. Data for the most recent follow-up, Wave IV, were collected in 2008 when participants were 24 to 32 years old $(n=15,701)$. Wave III and Wave IV follow-ups include adolescents interviewed as part of the original Wave I sample. Response rates were $79 \%, 88.6 \%, 77.4 \%$, and $80.3 \%$, respectively, across the four waves (Harris 2013). Using the Add Health respondent identifier, I linked respondent information across the four waves.

\subsection{Analytic Sample}

I use logistic regression to model the relationship between ACEs and timely graduation from college. I accounted for the stratified and clustering design of the data by using the Add Health recommended svy prefix in Stata 15, the appropriate cross-sectional weights, primary sampling unit variable, and strata in the analysis. The cross-sectional weights include Wave I respondents who were also interviewed in Wave IV (Chen and Chantala 2014). After applying the weights, there are 14,800 cases with valid weights. Similar to other research, I investigated timely bachelor's degree attainment given high school completion (Wojtkiewicz and Holtzman 2011). Close to 1300 cases were not included in the sample because they did not graduate from high school as indicated in Wave IV or if respondents that stated they had at least obtained a bachelor's degree for their highest education achieved in Wave IV but did not provide the year they received their degree. The final sample size for the analysis was 13,446 cases.

\subsection{Measures}

\subsubsection{Timely Bachelor's Degree Completion}

Similar to Fomby (2013), I define bachelor's degree completion by age 24-a group that has been defined as "fast starters." I constructed the binary outcome variable-timely bachelor's degree attainment-using Waves III and IV of the Add Health. In Wave IV, participants were asked what their highest level of education achieved to date was. Response choices included: 1 "8th grade or less," 2 "some high school," 3 "high school graduate," 4 "some vocational/technical training (after high school)," 5 "completed vocational/technical training (after high school)," 6 "some college," 7 "completed college (bachelor's degree)," 8 "some graduate school," 9 "completed a master's degree," 10 "some graduate training beyond a master's degree," 11 "completed a doctoral degree," 12 "some post baccalaureate 
professional education (e.g., law school, med school, nurse)," and 13 "completed post baccalaureate professional education (e.g., law school, med school, nurse)." Responses 7 and above were recoded to 1 and responses 6 and below to 0 .

In Wave IV, participants were asked to list their eight most recent degrees received, and the year they received the degree or certificate. To construct timely bachelor's degree attainment for Wave IV, I created a binary variable from the responses to reflect whether their most recent degree was a bachelor's degree. If it was a bachelor's degree, I used the year they received their degree and their birth year to calculate whether they received their degree by the age of 24 . If respondents were 24 years old or younger when they received their bachelor's degree, then this variable was coded as 1 for timely bachelor's degree. However, if respondents received a degree but did not complete it by age 24 , then timely bachelor's degree was coded to 0 .

In Wave III, respondents were asked "What degrees or diplomas have you received?" As separate questions, degrees were listed and respondents marked whether they had received a given degree or not $(1=$ yes; $0=$ no). The degrees or diplomas included: General Education Development (GED) or high school equivalency degree, high school diploma, associate or junior college, bachelor's degree, master's degree, doctoral degree, and professional degree. Respondents were also asked in what month and year they received their degree. To create the overall timely bachelor's degree variable for Wave III, I used the responses to whether they had received a bachelor's degree, what year and month they received it in, and their birth month and birth year as reported in Wave III. Similar to in Wave IV, I first subtracted their birth year from the year they received their bachelor's degree to calculate their age when they completed their bachelor's degree. However, because Wave III also included their birth month, I subtracted the month they received their degree from their birth month. If this was negative, then I subtracted a year from the given year. Then, I created a timely bachelor's degree variable with Wave III, coding those that were 24 or younger at the time they completed their bachelor's degree to 1 and everyone else to 0 .

Finally, I created an overall timely bachelor's degree variable for the entire sample. I gave priority to Wave IV responses and then filled in missing values using Wave III responses. Because there were respondents that had received a bachelor's degree but had missing information as to when they received their degree, I was not able to calculate their age at the time they received their degree so I excluded these cases from the analysis (approximately 950 cases). Those coded as zero in the overall timely bachelor's degree were respondents that had a bachelor's degree, but they had not graduated in a timely manner, and other participants that had at least a high school diploma but had not received a bachelor's degree or any other graduate or post-graduate degree by Wave IV.

\subsubsection{ACEs Measure}

I constructed the ACE scale using Waves I, III, and IV of the Add Health. The scale is modeled after Felitti et al. (1998) ACE questionnaire design. The ACE measures ask about key adverse events before the age of 18. The Add Health asked respondents regarding emotional, physical, and sexual abuse, neglect, parental fights and arguments, household substance abuse, parental warmth, parental separation or divorce, mental illness in the home, and parental incarceration. Below, I further explain the measures that were used to create the $10 \mathrm{ACE}$ component indicators in the current research. See Appendix A for a summary of these measures alongside the ACE questionnaire and those used to construct the ACEs measures in Add Health.

Emotional Abuse. Abuse and neglect questions in young childhood and adolescence were asked in Waves III and IV. Emotional abuse before age 18 was assessed retrospectively in Wave IV. Respondents were asked "Before your 18th birthday, how often did a parent or other adult caregiver say things that really hurt your feelings or made you feel like you were not wanted or loved?" Response choices included: (1) one time, (2) two times, (3) three to five times, (4) six to ten times, (5) more than ten times, and (6) this never happened. 
I created a dichotomous variable coding one time or more as 1 and "this never happened" to 0 . Unlike other abuse and neglect measures, this question was not asked in Wave III.

Physical Abuse. In Wave III respondents were asked if by the time they started 6th grade their parents or other adult caregivers ever slapped, hit, or kicked them, and how often, if it ever happened. Responses were coded to 1 if this occurred at least one time and 0 for "this never happened."

Sexual Abuse. In Wave III, sexual abuse occurring before the 6th grade was assessed. Study participants were asked if and how often their parents or other adult caregivers touched them in a sexual way, forced them to touch him or her in a sexual way, or forced them to have sexual relations. Reponses were dichotomized to 1 if this occurred at least once and 0 if it never happened.

Emotional Neglect. In Wave I, respondents were asked on a scale of 1 "strongly agree" to 5 "strongly disagree" how much they agreed with "Most of the time your mother is warm and loving toward you" and "Most of the time, your father is warm and loving toward you." Binary variables were created for each question, participants that responded strongly disagree for either the mother or father were coded as 1 while responses strongly agree to disagree on the Likert scale for both mother and father were coded as 0 . If the respondent did not have either a father or mother in the household, then the item only used the sole parent's response for emotional neglect.

Physical Neglect. Neglect in childhood was asked retrospectively in Wave III. Participants responded to "By the time you started 6th grade, how often had your parents or other adult care-givers left you home alone when an adult should have been with you?" and "By the time you started 6th grade, how often had your parents or other adult care-givers not taken care of your basic needs, such as keeping you clean or providing food or clothing?" Response choices for both included: (1) one time, (2) two times, (3) three to five times, (4) six to ten times, (5) more than ten times, and (6) this never happened. These responses were dichotomized for each response with 1 being "at least one time" and 0 "this never happened". After recoding these variables, if either response was a 1, neglect was coded as 1. However, if responses to both were 0 , then neglect was coded as 0 .

Parental Separation or Divorce. As part of Wave I, in the parental questionnaire, the parent respondent or parental figure was asked whether the youth's biological mother lives in the household ( $1=$ yes, $0=$ no). In a separate question, they were asked if the youth's biological father lives in the household. If the parent responded no to both or either biological mother and father living in the home, the parental separation or divorce measure was coded as 1 . However, if the respondent stated that both the biological mother and father were living in the home, parental separation or divorce was coded as 0 .

Mother Treated Violently. As part of the parental questionnaire, parents (and parental figures) were asked "How much do you fight or argue with your current spouse or partner?" The response scale was 1 "a lot," 2 "some," 3 "a little," 4 "not at all" or 7 "legitimate skip (no current spouse or partner)." To most closely align with the CDC measures and guidelines and the ACE questionnaire, I created a binary variable from this measure with 1 being cases that indicated that they fought or argued a lot with their current spouse of partner and 0 for those that responded some, a little, or not at all. If the parent respondent had no current spouse or partner, these cases were recoded as 0 .

Household Substance Abuse. Alcoholism was assessed in Wave I as part of the parental questionnaire. Respondents were asked if the youth's biological father was an alcoholic and or if the youth's mother was an alcoholic. Response choices for each was a binary variable, 1 "yes" or 0 "no."

In Wave I, adolescents were asked about the availability of illegal drugs in their home. Response choices included 1 "yes" or 0 "no." To follow the CDC definition of household substance abuse and the ACE questionnaire, I combined the responses to parental alcoholism and illegal drug availability in the home to create a dichotomous variable: household substance abuse. If the responses to either parental alcoholism or illegal drug availability was 1 "yes," then household substance abuse was coded as 1 . If the 
responses for both parental alcoholism and illegal drug availability were coded as zero, then household substance abuse is also zero.

Mental Illness in the Household. In Wave I, as part of the parental questionnaire, respondents were asked if they were currently happy and about their current spouse or partner's happiness. Respondents answered 1 "yes" or 0 "no" for each question (or 7 "legitimate skip (no current spouse or partner) for the current spouse or partner's happiness). The responses were then reverse coded to indicate that the respondent was unhappy (1) or happy (0). Following this, I combined both responses; if either respondent was coded as 1 or if the main respondent was unhappy and they had no current spouse or partner, then they were generally unhappy (1). Moreover, if both the respondent and the current spouse or partner were (0) or the respondent was happy and they had no current spouse or partner, then they were categorized as generally happy (0). Also, in the adolescent questionnaire, in Wave I, respondents asked whether $(1=$ yes; $0=$ no) "any of your family tried to kill themselves during the past 12 months?"

To create an ACE indicator, I combined the generally unhappy and happy variable (created from the respondent and the current spouse or partner's response, if they had a current spouse or partner) (see above for more details) and whether they had a family member who tried to kill themselves during the past 12 months. If the response for either the generally happy or unhappy variable or if family had tried to kill themselves during the past 12 months was 1 , then the ACE component indicator-mental illness in household-was coded as 1.

Criminal Involvement by Household Member. In Wave IV, the young adult sample was asked about their parents' incarceration history. They were asked, "(Has/did) your biological mother ever (spent/spend) time in jail or prison?"; "(Has/did) your (mother figure) ever (spent/spend) time in jail or prison?"; "(Has/did) your (biological father) ever (spent/spend) time in jail or prison?"; and "(Has/did) your (father figure) ever (spent/spend) time in jail or prison?" Participants answered "yes" (1) or "no" (0) for each question. Respondents were also asked how old they were (in years) at the time the respective parent went to jail or prison. For the ACE component indicator, I first combined the responses of the biological mother and mother figure and then did the same but for the biological father and the father figure.

To create a general measure for whether a parent ever went to jail or prison, similar to other studies (Hagan and Foster 2012; Mears and Siennick 2016; Nichols et al. 2016), I used the biological mother, mother figure, biological father, and father figure questions mentioned above and the age of the sample respondent when this happened. Because many of the questions used to create the ACE indictors, from the Add Health, ask about traumatic experiences before the 6th grade, I only considered parental incarceration that occurs after the child's birth and up until the age of 12. I followed the same cutoff for all four measures. Hence, for the respondent age, I created a new binary age variable where ages 13 or older and "not yet born" were coded as 0 and responses from "less than 1 year" to "12 years" were coded as 1 .

First, I created a general maternal incarceration variable and a general paternal incarceration variable. For the biological mother and mother figure incarceration questions, I created separate binary variables $(1=$ yes; $0=$ no). In addition, for the mother figure incarceration question, I also recoded all legitimate skips (7) to 0 . Following this, I created the general maternal incarceration variable. If the respondent stated that either their biological mother or their mother figure went to jail or prison and the binary age variable is equal to 1 (indicting before age 13 but after birth), then the general maternal incarceration variable is coded as 1. If the respondent stated that their biological mother went to jail or prison, but the binary age variable is 0 and the mother figure also went to jail or prison but the binary age variable is also 0 then maternal incarceration is coded as 0 . I followed the same steps in creating the general paternal incarceration variable.

After creating both the general maternal incarceration and the general paternal incarceration variables, I created the criminal involvement by household member ACE indicator. 
If either the general maternal incarceration variable or the general paternal incarceration variable was coded as 1 , then criminal household member status is coded as 1 . If both measures were coded as 0 , then the criminal household member status is coded as 0 .

\subsubsection{ACE Score}

To create the ACE score, and following the ACE literature, I created a scale that added the $10 \mathrm{ACE}$ components above, resulting in a range of zero ACEs to a maximum possibility of ten (Dube et al. 2001; Felitti et al. 1998; Gilbert et al. 2015; Shin et al. 2009; Shin et al. 2013).

\subsubsection{Control Variables}

The current study includes potential confounders of the ACEs/timely bachelor's degree attainment association and are drawn primarily from Waves I and IV (see Table 1 for variable descriptions). Similar to other research examining ACEs and educational attainment (Giovanelli et al. 2016; Skalamera and Hummer 2016), I controlled for the highest parental education reported, public assistance receipt, and logged income in Wave I. In addition, I controlled for adolescent's aspirations and expectations for college attendance in Wave I (Fomby 2013; Hossler and Stage 1992), students' age in Wave IV (which I created using the respondent's year and month of birth and available information on month and year of the Wave I interview), as well as sex and race in Wave I (Doyle and Grace 2007). The Add Health Picture Vocabulary Test (AHPVT) raw scores, the Add Health abridged version of the Peabody Vocabulary Test, known in the literature to be a proxy for cognitive ability, and a parent-reported measure of whether the student has a learning disability in Wave I are also included (French et al. 2015).

\subsubsection{Potential Mediators}

Depression. The socio-emotional measure is a depression scale. In the Add Health, depression is measured by the Center for Epidemiologic Studies Depression scale for Children (CES-DC), a reliable and valid scale measuring depression symptoms in the general population and among adolescent samples (Carey et al. 1987; Shin et al. 2013). At Wave I and Wave II the scale includes 19 items meanwhile Wave III and Wave IV include a nine-item subset. Similar to other studies looking at depressive symptoms, I use the nine-item subset at Wave I: how often during the past week the respondent felt bothered, could not shake off the blues, felt as good as other people, felt distracted, depressed, too tired to do things, enjoyed life, felt sad, and felt that people disliked them (Hall et al. 2017; Wilkinson et al. 2016). Respondents selected responses from a Likert scale: 0 "never or rarely," 1 "sometimes," 2 "a lot of the time," and 3 "most of the time or all of the time." Responses to feeling as good as others, and enjoying life were reverse coded to align with the sentiment of the other responses. The responses were totaled for a range of 0 to 27 .

General Health. I include self-rated general health measure from Wave I. Participants rated their overall general health on a scale from 1 "excellent," 2 "very good," 3 "good," 4 "fair," and 5 "poor." I reverse-coded this question so that a higher value coincided with better general health.

\subsection{Missing Values}

For measures such as sexual and physical abuse, since they were also investigated in Wave IV, albeit from somewhat of a different reference period, I used Wave IV to replace the missing values in Wave III. Similarly, if depression scale questions were missing in Wave I, I used Wave II responses to replace the missing values, when available. I also used the student reported household roster to fill in the missing data from the parent survey, specifically for parental separation or divorce. Lastly, I used multiple imputation to fill in the missing values in my data by creating 20 datasets using the mi command in Stata. As part of the multiple imputation equation, I included all the variables used in the analysis, including the dependent variable (Rubin 1996). However, I only used non-imputed cases from the dependent variable in the final analysis. 
Table 1. Description of Variables (weighted).

\begin{tabular}{|c|c|c|c|}
\hline & & Mean & SD \\
\hline \multicolumn{4}{|l|}{ Dependent Variable: } \\
\hline Timely Bachelor's Degree Attainment & $\begin{array}{c}\mathrm{BA}=1 \\
\mathrm{No} B A=0\end{array}$ & 0.26 & - \\
\hline $\begin{array}{l}\text { Independent Variable: } \\
\text { Adverse Childhood Experiences (ACES) } \\
\text { Physical and Socio-emotional Well-being } \\
\text { General Health }\end{array}$ & & 2.12 & 1.61 \\
\hline $\begin{array}{l}\text { Self-reported health in Wave I; ranges from } 1 \text { "poor" to } \\
5 \text { "excellent" }\end{array}$ & & 3.89 & 0.90 \\
\hline $\begin{array}{l}\text { Depression } \\
\text { Scale of } 9 \text { measures self-reported in Wave I; ranges from } 0 \\
\text { to } 27 \\
\text { Highest Parental Education Level }\end{array}$ & & 5.61 & 4.15 \\
\hline Highest education level received by either parent in Wave I. & & $\begin{array}{c}\text { Less than HS }=0.10 \\
\text { HS }=0.38 \\
\text { Some College }=0.20 \\
\text { BA } / S \text { or higher }= \\
0.33\end{array}$ & - \\
\hline \multicolumn{4}{|l|}{ Family Income } \\
\hline $\begin{array}{l}\text { Parent reported household income before taxes (logged) in } \\
\text { Wave I } \\
\text { Public Assistance }\end{array}$ & & 10.42 & 0.88 \\
\hline $\begin{array}{l}\text { Currently receiving public assistance (parent-reported in } \\
\text { Wave I) } \\
\text { College Going }\end{array}$ & $\begin{array}{l}\text { Yes }=1 \\
\text { No }=0\end{array}$ & 0.08 & - \\
\hline Aspirations & $\begin{array}{l}\text { How much do you } \\
\text { want to go to college; } \\
\quad \text { scale } 1-5 \\
\text { How likely is it that }\end{array}$ & 4.44 & 1.02 \\
\hline Expectations & $\begin{array}{l}\text { you will go to } \\
\text { college; scale } 1-5\end{array}$ & 4.17 & 1.14 \\
\hline \multicolumn{4}{|l|}{$\begin{array}{l}\text { Other Controls } \\
\text { Learning disability }\end{array}$} \\
\hline Have specific learning disability; parent-reported in Wave I & $\begin{array}{l}\text { Yes }=1 \\
\text { No }=0\end{array}$ & 0.13 & - \\
\hline $\begin{array}{l}\text { Cognitive Achievement } \\
\text { Add Health Vocab Test administered in Wave I; scores range } \\
\text { from } 14 \text { to } 146\end{array}$ & & 65.94 & 10.43 \\
\hline 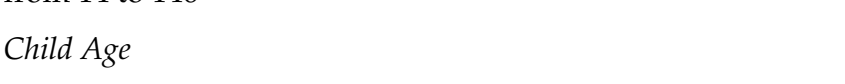 & $\begin{array}{l}\text { Current age in years; } \\
\text { ranges from } 25 \text { to } 34\end{array}$ & 28.98 & 1.86 \\
\hline Child Sex & Male $=1 ;$ Female $=0$ & 0.50 & - \\
\hline Child Race & $\begin{aligned} \text { White }= & 1 ; \text { Nonwhite } \\
& =0\end{aligned}$ & 0.67 & - \\
\hline
\end{tabular}

\subsection{Analysis Plan}

Below, I present weighted descriptive statistics for the current sample, including the distribution of ACEs scores. I used logistic regression given that the dependent variable is a dichotomous variable representing whether students received their bachelor's degree in a timely matter or not. Next, in Table 3, I present block models and the full model for the analysis. Model 1 shows the relationship between ACEs and timely bachelor's degree, with the controls. In Model 2, I examine the relationship between physical health, and depression, including controls, and timely bachelor's degree attainment but exclude the main independent variable-ACEs - to examine whether the potential mediating factors have a significant relationship with the dependent variable in the absence of the 
independent variable. In Models 3, 4, and 5, I examine whether general health and or mental health mediate the relationship between ACEs and timely bachelor's degree attainment.

\section{Results}

Table 1 provides a summary of the weighted descriptive statistics for all the variables in the analysis. Table 1 reveals that close to $26 \%$ of the sample had graduated in a timely manner by Wave IV. The ACE score mean is around 2, which is higher than the ACE data provided by the CDC-Kaiser Permanente ACE Study (CDC n.d.) and higher than the same age segment in Felitti et al. (1998). About one-third of the sample has at least one parent that holds a bachelor's degree or higher degree. Approximately $8 \%$ of the households receive public assistance. Overall, this sample has high aspirations and expectations to go to college scoring 4.44 and 4.17 out of 5, respectively. Close to $13 \%$ of the sample had some type of learning disability. The average age in Wave IV is about 29 years old, half of the sample is male, and $67 \%$ of the sample identifies as only white. Figure 2 displays the weighted distribution of ACEs as it is typically illustrated in the ACEs literature in five categories: $0,1,2,3$, and 4 plus. $^{1}$

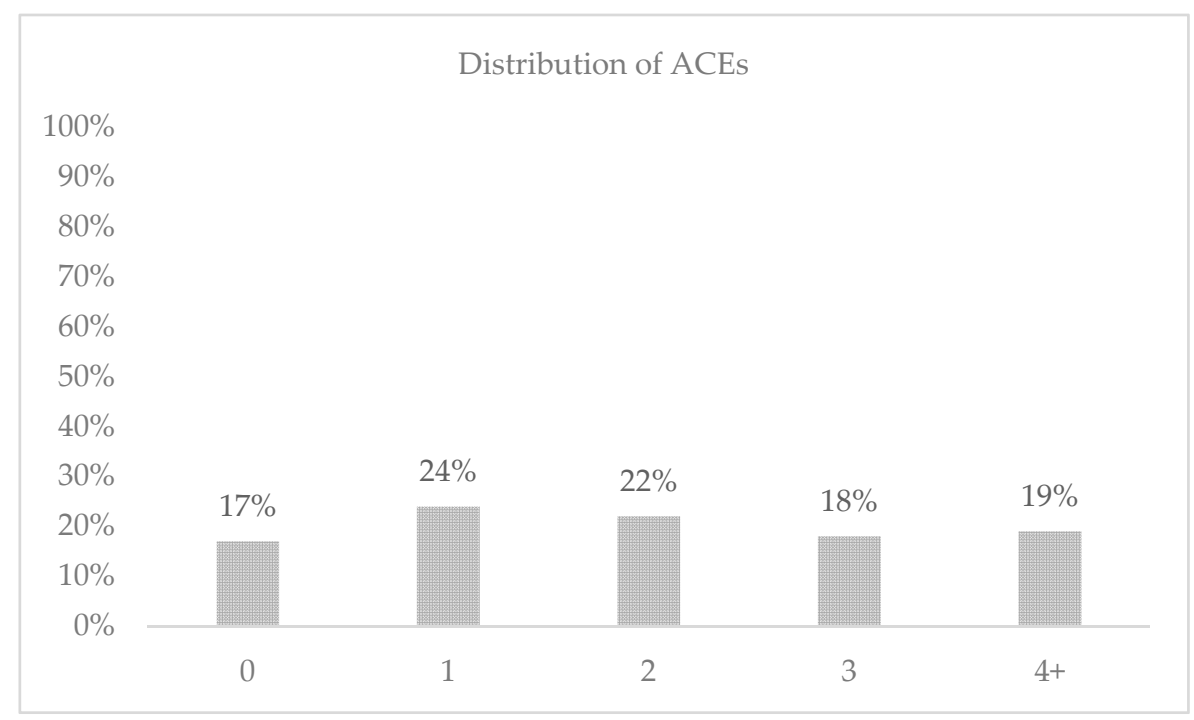

Figure 2. Distribution of ACEs Scores (weighted). $n=13,446$.

Are ACEs associated with timely bachelor's degree attainment? Table 2 Model 1 shows that there is a relationship between ACEs and timely bachelor's degree attainment. The relationship is significant-each additional ACE score is associated with a $29 \%$ decrease in the odds of timely graduation from college. In the full model (Model 5) this negative relationship persists, an additional ACE decreases the odds of timely bachelor's degree attainment by $17 \%$, despite including controls.

1 In comparison to the CDC ACE study data referenced above, the current study sample has more incidences of ACEs. In the CDC study, $36 \%$ of individuals had no ACEs. This may be because of the age of the sample. The CDC sample is older, includes individuals that did not graduate from high school, has a larger proportion of both white and female participants. Furthermore, the study was not nationally representative or longitudinal. 
Table 2. Logistic regression (odds ratio) results of timely BA/BS attainment by ACEs.

\begin{tabular}{|c|c|c|c|c|c|}
\hline & Model 1 & Model 2 & Model 3 & Model 4 & Model 5 \\
\hline ACEs & $\begin{array}{l}0.718^{* * *} \\
(0.016)\end{array}$ & $\begin{array}{l}0.820^{* * *} \\
(0.018)\end{array}$ & $\begin{array}{l}0.828^{* * *} \\
(0.019)\end{array}$ & $\begin{array}{l}0.829 * * * \\
(0.019)\end{array}$ & $\begin{array}{c}0.833^{* * *} \\
(0.019)\end{array}$ \\
\hline \multicolumn{6}{|c|}{ Physical/Socio-emotional Wellbeing } \\
\hline General Health & & & & $\begin{array}{l}1.390 * * * \\
(0.057)\end{array}$ & $\begin{array}{c}1.375^{* * *} \\
(0.058)\end{array}$ \\
\hline Depression & & & $\begin{array}{l}0.974 * * * \\
(0.007)\end{array}$ & & $\begin{array}{c}0.988 \\
(0.008)\end{array}$ \\
\hline \multicolumn{6}{|c|}{$\begin{array}{l}\text { Highest Parental Education Level } \\
\text { Reference: High School }\end{array}$} \\
\hline Less than HS & & $\begin{array}{c}0.797 \\
(0.163)\end{array}$ & $\begin{array}{c}0.805 \\
(0.166)\end{array}$ & $\begin{array}{c}0.806 \\
(0.166)\end{array}$ & $\begin{array}{c}0.809 \\
(0.167)\end{array}$ \\
\hline Some College & & $\begin{array}{l}1.047 \\
(0.106)\end{array}$ & $\begin{array}{l}1.040 \\
(0.105)\end{array}$ & $\begin{array}{l}1.029 \\
(0.105)\end{array}$ & $\begin{array}{l}1.027 \\
(0.105)\end{array}$ \\
\hline Bachelor's degree or higher & & $\begin{array}{l}2.572^{* * *} \\
(0.239)\end{array}$ & $\begin{array}{l}2.571 * * * \\
(0.241)\end{array}$ & $\begin{array}{l}2.526^{* * *} \\
(0.241)\end{array}$ & $\begin{array}{c}2.527^{* * *} \\
(0.242)\end{array}$ \\
\hline Family Income & & $\begin{array}{l}1.573^{* * *} \\
(0.119)\end{array}$ & $\begin{array}{l}1.583^{* * *} \\
(0.120)\end{array}$ & $\begin{array}{l}1.572^{* * *} \\
(0.120)\end{array}$ & $\begin{array}{c}1.577^{* * *} \\
(0.120)\end{array}$ \\
\hline Public Assistance & & $\begin{array}{c}0.792 \\
(0.166)\end{array}$ & $\begin{array}{c}0.796 \\
(0.168)\end{array}$ & $\begin{array}{c}0.792 \\
(0.169)\end{array}$ & $\begin{array}{c}0.794 \\
(0.170)\end{array}$ \\
\hline \multicolumn{6}{|l|}{ College Going } \\
\hline Aspirations & & $\begin{array}{c}1.451^{* * *} \\
(0.098)\end{array}$ & $\begin{array}{c}1.435^{* * *} \\
(0.097)\end{array}$ & $\begin{array}{c}1.422 * * * \\
(0.095)\end{array}$ & $\begin{array}{c}1.416^{* * *} \\
(0.095)\end{array}$ \\
\hline Expectations & & $\begin{array}{c}2.048^{* * *} \\
(0.135)\end{array}$ & $\begin{array}{c}2.013^{* * *} \\
(0.134)\end{array}$ & $\begin{array}{c}1.970 * * * \\
(0.130)\end{array}$ & $\begin{array}{c}1.957 * * * \\
(0.130)\end{array}$ \\
\hline \multicolumn{6}{|l|}{ Other Controls } \\
\hline Learning Disability & & $\begin{array}{c}0.313^{* * *} \\
(0.051)\end{array}$ & $\begin{array}{c}0.315^{* * *} \\
(0.051)\end{array}$ & $\begin{array}{c}0.330 * * * \\
(0.054)\end{array}$ & $\begin{array}{c}0.330^{* * *} \\
(0.054)\end{array}$ \\
\hline Cognitive Achievement & & $\begin{array}{c}1.051^{* * *} \\
(0.005)\end{array}$ & $\begin{array}{c}1.050 * * * \\
(0.005)\end{array}$ & $\begin{array}{c}1.052 * * * \\
(0.005)\end{array}$ & $\begin{array}{c}1.051^{* * *} \\
(0.005)\end{array}$ \\
\hline Child Age & & $\begin{array}{c}0.907^{* * *} \\
(0.021)\end{array}$ & $\begin{array}{c}0.914^{* * *} \\
(0.022)\end{array}$ & $\begin{array}{c}0.908^{* * *} \\
(0.022)\end{array}$ & $\begin{array}{c}0.911^{* * *} \\
(0.022)\end{array}$ \\
\hline Child Sex & & $\begin{array}{c}0.679 \text { *** } \\
(0.050)\end{array}$ & $\begin{array}{c}0.658^{* * *} \\
(0.049)\end{array}$ & $\begin{array}{c}0.635^{* * *} \\
(0.047)\end{array}$ & $\begin{array}{c}0.627^{* * *} \\
(0.047)\end{array}$ \\
\hline Child Race & & $\begin{array}{l}0.801 * \\
(0.077)\end{array}$ & $\begin{array}{l}0.795 * \\
(0.077)\end{array}$ & $\begin{array}{l}0.794 * \\
(0.077)\end{array}$ & $\begin{array}{l}0.792 * \\
(0.077)\end{array}$ \\
\hline Constant & $\begin{array}{c}0.648^{* * *} \\
(0.061)\end{array}$ & $\begin{array}{c}0.000 * * * \\
(0.000)\end{array}$ & $\begin{array}{c}0.000 * * * \\
(0.000)\end{array}$ & $\begin{array}{c}0.000 * * * \\
(0.000)\end{array}$ & $\begin{array}{c}0.000 * * * \\
(0.000)\end{array}$ \\
\hline$n$ & 13,446 & 13,446 & 13,446 & 13,446 & 13,446 \\
\hline
\end{tabular}

Note: ${ }^{*} p<0.05,{ }^{* *} p<0.01,{ }^{* * *} p<0.001$.

Does general health or socio-emotional well-being mediate the relationship between ACEs and timely bachelor's degree attainment? In Model 2, physical health and depression have a significant association with timely bachelor's degree attainment in the absence of ACEs, although general health is more pronounced. A one unit increase in general health is associated with a $39 \%$ increase in the odds of timely college graduation (Model 3). Using the sureg command in Stata (UCLA Consulting Group n.d.), I find that depression general health partially mediates the relationship between ACEs and timely bachelor's degree. Yet, in Model 5, including general health and depression into the analysis does not largely reduce the odd ratios and depression is no longer significant. This suggests that once 
considering general health, depression may not be a strong mediator of the relationship between ACEs and timely bachelor's degree attainment.

\subsection{Additional Findings}

As expected, Model 5 (Table 2) further shows that having a parent with at least a bachelor's degree significantly increases the odds of timely bachelor's degree attainment. In addition, higher family income increases the odds of timely bachelor's degree attainment. However, public assistance does not seem to affect timely bachelor's degree attainment. In addition, and consistent with previous research, having high aspirations and expectations to attend college increases the likelihood of timely bachelor's degree attainment. Having a learning disability significantly decreases the odds of timely bachelor's degree attainment meanwhile having higher cognitive ability increases the odds of timely completion. In line with the literature, I find that males are significantly less likely to graduate from college on time, and that older individuals are less likely to graduate within six years from college. Lastly, white adolescents are significantly less likely to graduate on time from college (albeit marginally).

\subsection{Nonlinear Analysis}

Table 3 shows the results for when ACEs is analyzed in 0,1,2,3,4+ categories instead of a linear measure. Overall, the findings, including controls, are similar to those in Table 2. However, in the full model, those with an ACEs score of one are not significantly different in their odds of obtaining a bachelor's degree compared to those with no ACEs, even when including controls. Compared to individuals that have no ACEs, individuals with two ACEs are about $23 \%$ less likely to graduate on time. Individuals with three ACEs are about $40 \%$ less likely meanwhile those with four (plus) are about $56 \%$ less likely to graduate in a timely manner.

Table 3. Logistic regression (odds ratio) results of timely BA/BS attainment by ACEs (0, 1, 2, 3, 4+).

\begin{tabular}{|c|c|c|c|c|c|}
\hline & Model 1 & Model 2 & Model 3 & Model 4 & Model 5 \\
\hline \multicolumn{6}{|l|}{ ACEs } \\
\hline 1 & $\begin{array}{c}0.741^{* *} \\
(0.068)\end{array}$ & $\begin{array}{c}0.849 \\
(0.084)\end{array}$ & $\begin{array}{c}0.861 \\
(0.085)\end{array}$ & $\begin{array}{c}0.859 \\
(0.088)\end{array}$ & $\begin{array}{c}0.864 \\
(0.088)\end{array}$ \\
\hline 2 & $\begin{array}{c}0.536^{* * *} \\
(0.046)\end{array}$ & $\begin{array}{c}0.736 \text { ** } \\
(0.073)\end{array}$ & $\begin{array}{c}0.754 \text { ** } \\
(0.074)\end{array}$ & $\begin{array}{c}0.763 \text { ** } \\
(0.076)\end{array}$ & $\begin{array}{l}0.770 * \\
(0.076)\end{array}$ \\
\hline 3 & $\begin{array}{c}0.364^{* * *} \\
(0.038)\end{array}$ & $\begin{array}{c}0.578^{* * *} \\
(0.067)\end{array}$ & $\begin{array}{c}0.597^{* * * *} \\
(0.070)\end{array}$ & $\begin{array}{l}0.602^{* * *} \\
(0.071)\end{array}$ & $\begin{array}{c}0.610^{* * *} \\
(0.072)\end{array}$ \\
\hline $4+$ & $\begin{array}{l}0.231^{* * *} \\
(0.026)\end{array}$ & $\begin{array}{l}0.415^{* * *} \\
(0.050)\end{array}$ & $\begin{array}{l}0.436^{* * *} \\
(0.053)\end{array}$ & $\begin{array}{l}0.437^{* * *} \\
(0.053)\end{array}$ & $\begin{array}{l}0.446^{* * *} \\
(0.055)\end{array}$ \\
\hline \multicolumn{6}{|c|}{ Physical/Socio-emotional Wellbeing } \\
\hline General Health & & & & $\begin{array}{l}1.392 * * * \\
(0.057)\end{array}$ & $\begin{array}{l}1.376^{* * *} \\
(0.058)\end{array}$ \\
\hline Depression & & & $\begin{array}{l}0.973^{* * *} \\
(0.007)\end{array}$ & & $\begin{array}{c}0.987 \\
(0.008)\end{array}$ \\
\hline \multicolumn{6}{|c|}{$\begin{array}{l}\text { Highest Parental Education Level } \\
\text { Reference: High School }\end{array}$} \\
\hline Less than HS & & $\begin{array}{c}0.794 \\
(0.162)\end{array}$ & $\begin{array}{c}0.802 \\
(0.163)\end{array}$ & $\begin{array}{c}0.803 \\
(0.164)\end{array}$ & $\begin{array}{c}0.807 \\
(0.165)\end{array}$ \\
\hline Some College & & $\begin{array}{c}1.041 \\
(0.105)\end{array}$ & $\begin{array}{c}1.035 \\
(0.105)\end{array}$ & $\begin{array}{c}1.024 \\
(0.104)\end{array}$ & $\begin{array}{c}1.022 \\
(0.104)\end{array}$ \\
\hline Bachelor's degree or higher & & $\begin{array}{c}2.571^{* * *} \\
(0.239)\end{array}$ & $\begin{array}{c}2.570 * * * \\
(0.241)\end{array}$ & $\begin{array}{c}2.526^{* * *} \\
(0.241)\end{array}$ & $\begin{array}{c}2.527^{* * *} \\
(0.242)\end{array}$ \\
\hline
\end{tabular}


Table 3. Cont.

\begin{tabular}{|c|c|c|c|c|c|}
\hline & Model 1 & Model 2 & Model 3 & Model 4 & Model 5 \\
\hline Family Income & & $\begin{array}{c}1.576^{* * *} \\
(0.118)\end{array}$ & $\begin{array}{c}1.586^{* * *} \\
(0.120)\end{array}$ & $\begin{array}{c}1.575^{* * *} \\
(0.119)\end{array}$ & $\begin{array}{c}1.580 \text { *** } \\
(0.120)\end{array}$ \\
\hline Public Assistance & & $\begin{array}{c}0.781 \\
(0.164)\end{array}$ & $\begin{array}{c}0.786 \\
(0.166)\end{array}$ & $\begin{array}{c}0.783 \\
(0.166)\end{array}$ & $\begin{array}{c}0.785 \\
(0.167)\end{array}$ \\
\hline \multicolumn{6}{|l|}{ College Going } \\
\hline Aspirations & & $\begin{array}{c}1.454^{* * *} \\
(0.098)\end{array}$ & $\begin{array}{c}1.438^{* * *} \\
(0.097)\end{array}$ & $\begin{array}{c}1.425^{* * *} \\
(0.095)\end{array}$ & $\begin{array}{c}1.419^{* * *} \\
(0.095)\end{array}$ \\
\hline Expectations & & $\begin{array}{c}2.051 * * * \\
(0.136)\end{array}$ & $\begin{array}{c}2.015^{* * *} \\
(0.134)\end{array}$ & $\begin{array}{c}1.973 * * * \\
(0.131)\end{array}$ & $\begin{array}{c}1.959^{* * *} \\
(0.130)\end{array}$ \\
\hline \multicolumn{6}{|l|}{ Other Controls } \\
\hline Learning Disability & & $\begin{array}{c}0.311 \text { *** } \\
(0.051)\end{array}$ & $\begin{array}{c}0.314^{* * *} \\
(0.051)\end{array}$ & $\begin{array}{c}0.328^{* * *} \\
(0.054)\end{array}$ & $\begin{array}{c}0.329^{* * *} \\
(0.054)\end{array}$ \\
\hline Cognitive Achievement & & $\begin{array}{c}1.051^{* * *} \\
(0.005)\end{array}$ & $\begin{array}{c}1.050 * * * \\
(0.005)\end{array}$ & $\begin{array}{c}1.052^{* * *} \\
(0.005)\end{array}$ & $\begin{array}{c}1.051^{* * *} \\
(0.005)\end{array}$ \\
\hline Child Age & & $\begin{array}{c}0.907^{* * * *} \\
(0.021)\end{array}$ & $\begin{array}{c}0.914^{* * *} \\
(0.022)\end{array}$ & $\begin{array}{c}0.908^{* * *} \\
(0.022)\end{array}$ & $\begin{array}{c}0.911^{* * *} \\
(0.022)\end{array}$ \\
\hline Child Sex & & $\begin{array}{c}0.683^{* * *} \\
(0.050)\end{array}$ & $\begin{array}{c}0.661^{* * *} \\
(0.049)\end{array}$ & $\begin{array}{c}0.638^{* * *} \\
(0.047)\end{array}$ & $\begin{array}{c}0.629 * * * \\
(0.047)\end{array}$ \\
\hline Child Race & & $\begin{array}{l}0.803 * \\
(0.077)\end{array}$ & $\begin{array}{l}0.798^{*} \\
(0.077)\end{array}$ & $\begin{array}{l}0.797^{*} \\
(0.077)\end{array}$ & $\begin{array}{l}0.795^{*} \\
(0.077)\end{array}$ \\
\hline Constant & $\begin{array}{c}0.634^{* * *} \\
(0.068)\end{array}$ & $\begin{array}{c}0.000 * * * \\
(0.000)\end{array}$ & $\begin{array}{c}0.000 * * * \\
(0.000)\end{array}$ & $\begin{array}{c}0.000 * * * \\
(0.000)\end{array}$ & $\begin{array}{c}0.000^{* * *} \\
(0.000)\end{array}$ \\
\hline & 13,446 & 13,446 & 13,446 & 13,446 & 13,446 \\
\hline
\end{tabular}

Note: ${ }^{*} p<0.05,{ }^{* *} p<0.01,{ }^{* * *} p<0.001$.

\section{Discussion}

Until now, there has been little research examining ACEs and educational attainment (Giovanelli et al. 2016). In addition, there have been no ACE study using nationally longitudinal data to examine this relationship. In what I think is the first national assessment, I find that ACEs are significantly associated with timely bachelor's degree attainment. Even with an array of confounding factors accounted for, I find that an additional ACE is associated with a $17 \%$ decrease in the odds of timely bachelor's degree completion. Further, when looking at ACEs categorically in the analysis, those with four or more ACEs are $56 \%$ less likely to graduate within six years compared to those with no ACEs.

These findings provide a sobering window into how educational inequality is connected to the home and family context. In addition, they reveal new evidence for its long-reaching impact across the life course. Since traumatic issues are likely to co-occur and have cumulative effects on educational outcomes, programs seeking to decrease academic achievement-opportunity gaps and to improve educational attainment outcomes for all students should embrace a trauma-informed approach that considers how child adversity disrupts educational trajectories of American youth.

And although I find that general health partially mediates the relationship between ACEs and timely bachelor's degree completion, the impact is relatively small. I suggest future investigation into other aspects of socio-emotional well-being, such as externalizing behavior or anxiety and mood disorders.

I should note that this study has important limitations. The ACE Questionnaire and the questions that I used to construct the ACE scale from the Add Health do not match in their entirety. For instance, for the domestic violence measure, the Add Health asked respondents how often the parent respondent and their current spouse or partner fought or argued. The ACE Questionnaire, however, asks about whether the mother was treated violently (physically). Also, other limitations include omitted variable bias-I may not have accounted for a variable that would explain the relationship between ACEs and timely 
bachelor's degree attainment. If this were the case, the documented relationship could be spurious. Relatedly, this analysis is not causal and selection bias has not completely been accounted for.

Overall, this study contributes to the ACE literature by using a large, nationally representative sample to document a strong link between ACEs and educational attainment suggesting that non-school factors-even those in early childhood-are critically connected to educational attainment years later in early adulthood (Otero 2018).

Funding: This research received no external funding.

Institutional Review Board Statement: Ethical review and approval were waived for this study.

Informed Consent Statement: Not applicable.

Data Availability Statement: The data used for this study are restricted and are not publicly available without permission.

Acknowledgments: I thank Benjamin Gibbs for his mentorship and feedback on multiple drafts of this paper from its development as a master's thesis to now. I also thank the two anonymous reviewers.

Conflicts of Interest: The author declares no conflict of interest.

\section{Appendix A}

Table A1. ACE Questionnaire and ACE Add Health Measures.

\begin{tabular}{|c|c|c|c|c|}
\hline Domain & ACE Questionnaire & ACE Add Health Measures & Wave & Current Study \\
\hline & $\begin{array}{l}\text { While you were growing } \\
\text { up, during your first } 18 \\
\text { years of life: }\end{array}$ & & & \\
\hline Emotional abuse & $\begin{array}{l}\text { 1. Did a parent or other } \\
\text { adult in the household } \\
\text { often ... } \\
\text { Swear at you, insult you, } \\
\text { put you down, or } \\
\text { humiliate you? } \\
\text { or } \\
\text { Act in a way that made } \\
\text { you afraid that you might } \\
\text { by physically hurt? } \\
\text { Yes } \\
\text { No }\end{array}$ & $\begin{array}{l}\text { Before your 18th birthday, how often did a } \\
\text { parent or other adult caregiver say things } \\
\text { that really hurt your feelings or made you } \\
\text { feel like you were not wanted or loved? } \\
\text { 1. one time } \\
\text { 2. two times } \\
\text { 3. three to five times } \\
\text { 4. six to ten times } \\
\text { 5. more than ten times } \\
\text { 6. this never happened }\end{array}$ & IV & $\begin{array}{l}1=1 \text { time or more } \\
0=6 \text { this never } \\
\text { happened }\end{array}$ \\
\hline Physical Abuse & $\begin{array}{l}\text { 2. Did a parent or other } \\
\text { adult in the household } \\
\text { often ... } \\
\text { Push, grab, slap, or throw } \\
\text { something at you? } \\
\text { or } \\
\text { Ever hit you so hard that } \\
\text { you had marks or were } \\
\text { injured? } \\
\text { Yes } \\
\text { No }\end{array}$ & $\begin{array}{l}\text { Before the time you started } 6^{\text {th }} \text { grade, how } \\
\text { often had your parents or other adult } \\
\text { care-givers slapped, hit, or kicked you? } \\
\text { 1. one time } \\
\text { 2. two times } \\
\text { 3. three to five times } \\
\text { 4. six to ten times } \\
\text { 5. more than ten times } \\
\text { 6. this never happened }\end{array}$ & III & $\begin{array}{l}1=1 \text { time or more } \\
0=6 \text { this never } \\
\text { happened }\end{array}$ \\
\hline
\end{tabular}


Table A1. Cont.

\begin{tabular}{|c|c|c|c|c|}
\hline Domain & ACE Questionnaire & ACE Add Health Measures & Wave & Current Study \\
\hline Sexual Abuse & $\begin{array}{l}\text { 3. Did an adult or person at } \\
\text { least } 5 \text { years older than you } \\
\text { ever ... } \\
\text { Touch or fondle you or have } \\
\text { you touch their body in a } \\
\text { sexual way? } \\
\text { or } \\
\text { try to actually have oral, } \\
\text { anal, or vaginal sex with } \\
\text { you? } \\
\text { Yes } \\
\text { No }\end{array}$ & $\begin{array}{l}\text { Before the time you started } 6^{\text {th }} \text { grade, how often } \\
\text { had your parents or other adult care-givers } \\
\text { touched you in a sexual way, forced you to touch } \\
\text { him or her in a sexual way, or forced you to have } \\
\text { sexual relations? } \\
\text { 1. one time } \\
\text { 2. two times } \\
\text { 3. three to five times } \\
\text { 4. six to ten times } \\
\text { 5. more than ten times } \\
\text { 6. this never happened }\end{array}$ & III & $\begin{array}{l}1=1 \text { time or more } \\
0=6 \text { this never } \\
\text { happened }\end{array}$ \\
\hline Emotional Neglect & $\begin{array}{l}\text { 4. Did you often feel that ... } \\
\text { No one in your family loved } \\
\text { you or thought you were } \\
\text { important or special? } \\
\text { or } \\
\text { Your family didn't look out } \\
\text { for each other, feel close to } \\
\text { each other, or support each } \\
\text { other? } \\
\text { Yes } \\
\text { No }\end{array}$ & $\begin{array}{l}\text { Most of the time, your mother is warm and } \\
\text { loving toward you. } \\
\text { or } \\
\text { Most of the time, your father is warm and loving } \\
\text { toward you. } \\
\text { 1. strongly agree } \\
\text { 2. agree } \\
\text { 3. neither agree nor disagree } \\
\text { 4. disagree } \\
\text { 5. strongly disagree }\end{array}$ & I & $\begin{array}{l}1=5 \text { strongly disagree } \\
0=1 \text { strongly agree }-4 \\
\text { disagree }\end{array}$ \\
\hline Physical Neglect & $\begin{array}{l}\text { 5. Did you often feel that ... } \\
\text { You didn't have enough to } \\
\text { eat, had to wear dirty } \\
\text { clothes, and had no one to } \\
\text { protect you? } \\
\text { or } \\
\text { Your patents were too drunk } \\
\text { or high to take care of you or } \\
\text { take you to the doctor if you } \\
\text { needed it? } \\
\text { Yes } \\
\text { No }\end{array}$ & $\begin{array}{l}\text { By the time you started 6th grade, how often had } \\
\text { your parents or other adult care-givers left you } \\
\text { home alone when an adult should have been } \\
\text { with you? } \\
\text { or } \\
\text { By the time you started 6th grade, how often had } \\
\text { your parents or other adult care-givers not taken } \\
\text { care of your basic needs, such as keeping you } \\
\text { clean or providing food or clothing? } \\
\text { 1. one time } \\
\text { 2. two times } \\
\text { 3. three to five times } \\
\text { 4. six to ten times } \\
\text { 5. more than ten times } \\
\text { 6. this never happened }\end{array}$ & III & $\begin{array}{l}1=1 \text { time or more } \\
0=6 \text { this never } \\
\text { happened }\end{array}$ \\
\hline $\begin{array}{l}\text { Parental Separation or } \\
\text { Divorce }\end{array}$ & $\begin{array}{l}\text { 6. Were your parents ever } \\
\text { separated or divorced? } \\
\text { Yes } \\
\text { No }\end{array}$ & Constructed using parental questionnaire & I & $\begin{array}{l}1=\text { both biological } \\
\text { parents living in home } \\
0=\text { All other family } \\
\text { structures }\end{array}$ \\
\hline $\begin{array}{l}\text { Mother Treated } \\
\text { Violently }\end{array}$ & $\begin{array}{l}\text { 7. Was your mother or } \\
\text { stepmother: } \\
\text { Often pushed, grabbed, } \\
\text { slapped, or had something } \\
\text { thrown at her? } \\
\text { or } \\
\text { Sometimes or often kicked, } \\
\text { bitten, hit with a fist, or hit } \\
\text { with something had? } \\
\text { or } \\
\text { Ever repeatedly hit over at } \\
\text { least a few minutes or } \\
\text { threatened with a gun or } \\
\text { knife? } \\
\text { Yes } \\
\text { No }\end{array}$ & $\begin{array}{l}\text { How much do you fight or argue with your } \\
\text { current (spouse/partner)? } \\
\text { 1. a lot } \\
\text { 2. some } \\
\text { 3. a little } \\
\text { 4. not at all }\end{array}$ & I & $\begin{array}{l}1=1 \text { a lot } \\
0=2 \text { some }-4 \text { not at all }\end{array}$ \\
\hline
\end{tabular}


Table A1. Cont.

\begin{tabular}{|c|c|c|c|c|}
\hline Domain & ACE Questionnaire & ACE Add Health Measures & Wave & Current Study \\
\hline $\begin{array}{l}\text { Household Substance } \\
\text { Abuse }\end{array}$ & $\begin{array}{l}\text { 8. Did you live with anyone } \\
\text { who was a problem drinker } \\
\text { or alcoholic or who used } \\
\text { street drugs? } \\
\text { Yes } \\
\text { No }\end{array}$ & $\begin{array}{l}\text { Alcoholism ... } \\
\text { (His/her) biological father has? } \\
\text { or } \\
\text { (His/her) biological mother has? } \\
0 \text { no; } 1 \text { yes } \\
\text { or } \\
\text { Are illegal drugs easily available to you in your } \\
\text { home? } \\
0 \text { no; } 1 \text { yes }\end{array}$ & I & $\begin{array}{l}1=1 \text { yes } \\
0=0 \text { no }\end{array}$ \\
\hline $\begin{array}{l}\text { Mental Illness in } \\
\text { Household }\end{array}$ & $\begin{array}{l}\text { 9. Was a household member } \\
\text { depressed or mentally ill or } \\
\text { did a household member } \\
\text { attempt suicide? } \\
\text { Yes } \\
\text { No }\end{array}$ & $\begin{array}{l}\text { In general, are you (main parent respondent) } \\
\text { happy? } \\
\text { or } \\
\text { In general do you think (he/she) (main parent } \\
\text { respondent's partner or spouse) is happy? } \\
0 \text { no; } 1 \text { yes } \\
\text { or } \\
\text { Have any of your family tried to kill themselves } \\
\text { during the past } 12 \text { months? } \\
0 \text { no; } 1 \text { yes }\end{array}$ & I & $\begin{array}{l}1=1 \text { yes } \\
0=0 \text { no }\end{array}$ \\
\hline $\begin{array}{l}\text { Criminal Involvement } \\
\text { by Household Member }\end{array}$ & $\begin{array}{l}\text { 10. Did a household member } \\
\text { go to prison? } \\
\text { Yes } \\
\text { No }\end{array}$ & $\begin{array}{l}\text { (Has/did your biological mother ever } \\
\text { (spent/spend) time in jail or prison? } \\
\text { or } \\
\text { (Has/did) your biological father ever } \\
\text { (spent/spend) time in jail or prison? } \\
\text { or } \\
\text { (Has/did) your (mother figure) ever } \\
\text { (spent/spend) time in jail or prison? } \\
\text { or } \\
\text { (Has/did) your (father figure) ever (spent/spend) } \\
\text { time in jail or prison? } \\
0 \text { no; } 1 \text { yes }\end{array}$ & IV & $\begin{array}{l}1=1 \text { yes } \\
0=0 \text { no }\end{array}$ \\
\hline
\end{tabular}

\section{References}

Anda, Robert F., Vincent J. Felitti, J. Douglas Bremner, John D. Walker, Charles Whitfield, Bruce D. Perry, Shanta R. Dube, and Wayne H. Giles. 2006. The Enduring Effects of Abuse and Related Adverse Experiences in Childhood: A Convergence of Evidence from Neurobiology and Epidemiology. European Archives of Psychiatry and Clinical Neuroscience 256: 174-86. [CrossRef] [PubMed]

Anda, Robert F., Vladimir I. Fleisher, Vincent J. Felitti, Valerie J. Edwards, Charles L. Whitfield, Shanta R. Dube, and David F. Williamson. 2004. Childhood Abuse, Household Dysfunction, and Indicators of Impaired Adult Worker Performance. The Permanente Journal 8: 30. [CrossRef] [PubMed]

Anderson, Page L., Jasmin A. Tiro, Ann Webb Price, Marnette A. Bender, and Nadine J. Kaslow. 2002. Additive Impact of Childhood Emotional, Physical, and Sexual Abuse on Suicide Attempts among Low-Income African American Women. Suicide and Life-Threatening Behavior 32: 131-37. [CrossRef] [PubMed]

Balfanz, Robert, Liza Herzog, and Douglas J. Mac Iver. 2007. Educational Psychologist Preventing Student Disengagement and Keeping Students on the Graduation Path in Urban Middle-Grades Schools: Early Identification and Effective Interventions. Educational Psychologist 42: 223-35. [CrossRef]

Bethell, Christina D., Paul Newacheck, Eva Hawes, and Neal Halfon. 2014. Adverse Childhood Experience: Assessing The Impact On Health And School Engagement And The Mitigating Role Of Resilience. Health Affairs 33: 12. [CrossRef]

Brown, David W., Robert F. Anda, Vincent J. Felitti, Valerie J. Edwards, Ann Marie Malarcher, Janet B. Croft, and Wayne H. Giles. 2010. Erratum: Adverse Childhood Experiences Are Associated with the Risk of Lung Cancer: A Prospective Cohort Study. BMC Public Health 10: 20. [CrossRef]

Carey, Michael P., Michael E. Faulstich, Frank M. Gresham, Laurie Ruggiero, and Patience Enyart. 1987. Children's Depression Inventory: Construct and Discriminant Validity Across Clinical and Nonreferred (Control) Populations. Journal of Consulting and Clinical Psychology 55: 755-61. [CrossRef]

CDC. n.d. About the CDC-Kaiser ACE Study. Centers for Disease Control and Prevention. Available online: https://www.cdc.gov/ violenceprevention/aces/about.html (accessed on 31 October 2020).

Chapman, Daniel P., Anne G. Wheaton, Robert F. Anda, Janet B. Croft, Valerie J. Edwards, Yong Liu, Stephanie L. Sturgis, and Geraldine S. Perry. 2011. Adverse Childhood Experiences and Sleep Disturbances in Adults. Sleep Medicine 12: 773-79.

Chapman, Daniel P., Charles L. Whitfield, Vincent J. Felitti, Shanta R. Dube, Valerie J. Edwards, and Robert F. Anda. 2004. Adverse Childhood Experiences and the Risk of Depressive Disorders in Adulthood. Journal of Affective Disorders 82: 217-25. [CrossRef] 
Chartier, Mariette J., John R. Walker, and Barbara Naimark. 2010. Separate and Cumulative Effects of Adverse Childhood Experiences in Predicting Adult Health and Health Care Utilization. Child Abuse and Neglect 34: 454-64. [CrossRef]

Chen, Ping, and Kim Chantala. 2014. Guidelines for Analyzing Add Health Data. Chapel Hill: University of North Carolina at Chapel Hill.

Danese, Andrea, and Bruce S. McEwen. 2012. Adverse Childhood Experiences, Allostasis, Allostatic Load, and Age-Related Disease. Physiology E Behavior 106: 29-39.

Dong, Maxia, Robert F. Anda, Vincent J. Felitti, Shanta R. Dube, David F. Williamson, Theodore J. Thompson, Clifton M. Loo, and Wayne H. Giles. 2004. The Interrelatedness of Multiple Forms of Childhood Abuse, Neglect, and Household Dysfunction. Child Abuse \& Neglect 28: 771-84.

Douglas, Kara R., Grace Chan, Joel Gelernter, Albert J. Arias, Raymond F. Anton, Roger D. Weiss, Kathleen Brady, James Poling, Lindsay Farrer, and Henry R. Kranzler. 2010. Adverse Childhood Events as Risk Factors for Substance Dependence: Partial Mediation by Mood and Anxiety Disorders. Addictive Behaviors 35: 7-13. [CrossRef]

Doyle, Jamie Mihoko, and K. Grace. 2007. Are Racial Identities of Multiracials Stable? Changing Self-Identification among Single and Multiple Race Individuals. Social Psychology Quarterly 70: 405-23. [CrossRef]

Dube, Shanta R., David F. Williamson, Ted Thompson, Vincent J. Felitti, and Robert F. Anda. 2004. Assessing the Reliability of Retrospective Reports of Adverse Childhood Experiences among Adult HMO Members Attending a Primary Care Clinic. Child Abuse \& Neglect 28: 729-37.

Dube, Shanta R., Robert F. Anda, Vincent J. Felitti, Daniel P. Chapman, David F. Williamson, and Wayne H. Giles. 2001. Childhood Abuse, Household Dysfunction, and the Risk of Attempted Suicide throughout the Life Span: Findings from the Adverse Childhood Experiences Study. Journal of the American Medical Association 286: 3089-96. [CrossRef]

Dube, Shanta R., Michelle L. Cook, and Valerie J. Edwards. 2010. Health-Related Outcomes of Adverse Childhood Experiences in Texas, 2002. Preventing Chronic Disease 7: A52.

Eide, Eric R., and Mark H. Showalter. 2011. Estimating the Relation between Health and Education: What Do We Know and What Do We Need to Know? Economics of Education Review 30: 778-91. [CrossRef]

Evans, Gary W., Dongping Li, and Sara Sepanski Whipple. 2013. Cumulative Risk and Child Development. Psychological Bulletin 139: 1342. [CrossRef]

Felitti, Vincent J., Robert F. Anda, Dale Nordenberg, David F. Williamson, Alison M. Spitz, Valerie Edwards, Mary P. Koss, James S. Marks, and Kaiser Perma-Nente. 1998. Relationship of childhood abuse and household dysfunction to many of the leading causes of death in adults the adverse childhood experiences (ACE) study. American Journal of Preventive Medicine 14: 245-58. [CrossRef]

Flaherty, Emalee G., Richard Thompson, Howard Dubowitz, Elizabeth M. Harvey, Diana J. English, Laura J. Proctor, and Desmond K. Runyan. 2013. Adverse Childhood Experiences and Child Health in Early Adolescence. JAMA Pediatrics 167: 622-29. [CrossRef] [PubMed]

Fletcher, Jason M. 2008. Adolescent Depression: Diagnosis, Treatment, and Educational Attainment. Health Economics 17: 1215-35. [CrossRef] [PubMed]

Fletcher, Jason M. 2010. Adolescent Depression and Educational Attainment: Results Using Sibling Fixed Effects. Health Economics 19: 855-71. [CrossRef]

Fletcher, Jason M. 2011. The Medium Term Schooling and Health Effects of Low Birth Weight: Evidence from Siblings. Economics of Education Review 30: 517-27.

Fomby, Paula. 2013. Family Instability and College Enrollment and Completion. Population Research and Policy Review 32: 46994. [CrossRef]

Font, Sarah A., and Kathryn Maguire-Jack. 2016. Pathways from Childhood Abuse and Other Adversities to Adult Health Risks: The Role of Adult Socioeconomic Conditions. Child Abuse and Neglect 51: 390-99. [CrossRef] [PubMed]

French, Michael T., Jenny F. Homer, Ioana Popovici, and Philip K. Robins. 2015. What You Do in High School Matters: High School GPA, Educational Attainment, and Labor Market Earnings as a Young Adult. Eastern Economic Journal 41: 370-86. [CrossRef]

Gilbert, Leah K., Matthew J. Breiding, Melissa T. Merrick, William W. Thompson, Derek C. Ford, Satvinder S. Dhingra, and Sharyn E. Parks. 2015. Childhood Adversity and Adult Chronic Disease: An Update from Ten States and the District of Columbia, 2010. American Journal of Preventive Medicine 48: 345-49. [CrossRef]

Giovanelli, Alison, Arthur J. Reynolds, Christina F. Mondi, and Suh-Ruu Ou. 2016. Adverse Childhood Experiences and Adult Well-Being in a Low-Income, Urban Cohort. Pediatrics 137: e20154016. [CrossRef]

Grusky, David B., and Katherine Weisshaar. 2014. The Questions We Ask About Inequality. In Social Stratification: Class, Race, and Gender in Sociological Perspective. Boulder: Westview Press.

Hagan, John, and Holly Foster. 2012. Intergenerational Educational Effects of Mass Imprisonment in America. Sociology of Education 85: 259-86. [CrossRef]

Hall, Kelli S., Jennifer L. Richards, and Kathleen M. Harris. 2017. Social disparities in the relationship between depression and unintended pregnancy during adolescence and young adulthood. Journal of Adolescent Health 60: 688-97. [CrossRef]

Harris, Kathleen Mullan. 2013. The Add Health Study: Design and Accomplishments. Chapel Hill: Carolina Population Center, University of North Carolina at Chapel Hill.

Horan, Jacqueline M., and Cathy Spatz Widom. 2015. Cumulative Childhood Risk and Adult Functioning in Abused and Neglected Children Grown Up. Development and Psychopathology 27: 927-41. [CrossRef] 
Hossler, Don, and Frances K. Stage. 1992. Family and High School Experience Influences on the Postsecondary Educational Plans of Ninth-Grade Students. American Educational Research Journal Summer 29: 425-51. [CrossRef]

Hunt, Justin, Daniel Eisenberg, and Amy M. Kilbourne. 2010. Consequences of Receipt of a Psychiatric Diagnosis for Completion of College. Psychiatric Services 61: 399-404. [CrossRef] [PubMed]

Hurd, Noelle M., Fatima A. Varner, and Stephanie J. Rowley. 2013. Involved-Vigilant Parenting and Socio-Emotional Well-Being Among Black Youth: The Moderating Influence of Natural Mentoring Relationships. Journal of Youth and Adolescence 42: 158395. [CrossRef]

Jimenez, Manuel E., Roy Wade, Yong Lin, Lesley M. Morrow, and Nancy E. Reichman. 2016. Adverse Experiences in Early Childhood and Kindergarten Outcomes. Pediatrics 137: e20151839. [CrossRef] [PubMed]

Johnson, Monica Kirkpatrick, Jeremy Staff, John E. Schulenberg, and Megan E. Patrick. 2016. Living Healthier and Longer: A Life Course Perspective on Education and Health. In Handbook of the Life Course. Edited by M. J. Shanahan, J. T. Mortimer and M. Kirkpatrick Johnson. Cham: Springer International Publishing, pp. 369-88.

Kessler, Ronald C., Chris G. Davis, and K. S. Kendler. 1997. Childhood Adversity and Adult Psychiatric Disorder in the US National Comorbidity Survey. Psychological Medicine 27: 1101-19. [CrossRef]

Lamers-Winkelman, Francien, Agnes M. Willemen, and Margreet Visser. 2012. Adverse Childhood Experiences of Referred Children Exposed to Intimate Partner Violence: Consequences for Their Wellbeing. Child Abuse and Neglect 36: 166-79. [CrossRef]

Larkin, Heather, Joseph J. Shields, and Robert F. Anda. 2012. The Health and Social Consequences of Adverse Childhood Experiences (ACE) Across the Lifespan: An Introduction to Prevention and Intervention in the Community. Journal of Prevention E Intervention in the Community 40: 263-70.

Liu, Yong, Janet B. Croft, Daniel P. Chapman, Geraldine S. Perry, Kurt J. Greenlund, Guixiang Zhao, and Valerie J. Edwards. 2013. Relationship between Adverse Childhood Experiences and Unemployment among Adults from Five US States. Social Psychiatry and Psychiatric Epidemiology 48: 357-69. [CrossRef] [PubMed]

Maslow, Gary R., Abigail Haydon, Annie-Laurie Mcree, Carol A. Ford, and Carolyn T. Halpern. 2011. Growing Up with a Chronic Illness: Social Success, Educational/Vocational Distress. Journal of Adolescent Health 49: 206-12. [CrossRef]

McLaughlin, Katie A., Jennifer Greif Green, Michael J. Gruber, Nancy A. Sampson, Alan M. Zaslavsky, and Ronald C. Kessler. 2012. Childhood Adversities and First Onset of Psychiatric Disorders in a National Sample of US Adolescents. Archives of General Psychiatry 69: 1151-60. [CrossRef] [PubMed]

McLeod, Jane D., Ryotaro Uemura, and Shawna Rohrman. 2012. Adolescent Mental Health, Behavior Problems, and Academic Achievement. Journal of Health and Social Behavior 53: 482-97. [CrossRef]

Mears, Daniel P., and Sonja E. Siennick. 2016. Young Adult Outcomes and the Life-Course Penalties of Parental Incarceration. Journal of Research in Crime and Delinquency 53: 3-35. [CrossRef]

Mersky, J. P., J. Topitzes, and A. J. Reynolds. 2013. Impacts of Adverse Childhood Experiences on Health, Mental Health, and Substance Use in Early Adulthood: A Cohort Study of an Urban, Minority Sample in the U.S. Child Abuse and Neglect 37: 917-25. [CrossRef] [PubMed]

Monnat, Shannon M., and Raeven Faye Chandler. 2015. Long-Term Physical Health Consequences of Adverse Childhood Experiences. The Sociological Quarterly 56: 723-52. [CrossRef]

Morrow, Anne S., and Miguel T. Villodas. 2018. Direct and Indirect Pathways from Adverse Childhood Experiences to High School Dropout Among High-Risk Adolescents. Journal of Research on Adolescence 28: 327-41. [CrossRef]

Needham, Belinda L., Robert Crosnoe, and Chandra Muller. 2004. Academic failure in secondary school: The inter-related role of health problems and educational context. Social Problems 51: 569-86.

Needham, Belinda L. 2009. Adolescent Depressive Symptomatology and Young Adult Educational Attainment: An Examination of Gender Differences. Journal of Adolescent Health 45: 179-86. [CrossRef]

Nichols, Emily B., Ann B. Loper, and J. Patrick Meyer. 2016. Promoting Educational Resiliency in Youth with Incarcerated Parents: The Impact of Parental Incarceration, School Characteristics, and Connectedness on School Outcomes. Journal of Youth and Adolescence 45: 1090-1109. [CrossRef]

Nurius, Paula S., Sara Green, Patricia Logan-Greene, and Sharon Borja. 2015. Life Course Pathways of Adverse Childhood Experiences toward Adult Psychological Well-Being: A Stress Process Analysis. Child Abuse and Neglect 45: 143-53. [CrossRef]

Otero, Carolina. 2018. Adverse Childhood Experiences (ACEs) and Timely Bachelor's Degree Attainment. Theses and Dissertations. 6993. Available online: https:/ / scholarsarchive.byu.edu/etd/ 6993 (accessed on 27 January 2020).

Rees, Daniel I., and Joseph J. Sabia. 2011. The Effect of Migraine Headache on Educational Attainment. The Journal of Human Resources 46: 317-32. [CrossRef]

Rubin, Donald B. 1996. Multiple Imputation after 18+ Years. Journal of the American Statistical Association 91: 473-89. [CrossRef]

Sabia, Joseph J. 2007. The Effect of Body Weight on Adolescent Academic Performance. Southern Economic Association 73: 871-900.

Sewell, William H., Archibald O. Haller, and Alejandro Portes. 1969. The educational and early occupational attainment process. American Sociological Review 34: 82-92. [CrossRef]

Shin, Sunny H., Daniel P. Miller, and Martin H. Teicher. 2013. Exposure to Childhood Neglect and Physical Abuse and Developmental Trajectories of Heavy Episodic Drinking from Early Adolescence into Young Adulthood. Drug and Alcohol Dependence 127: 31-38. [CrossRef] 
Shin, Sunny Hyucksun, Erika Edwards, Timothy Heeren, and Maryann Amodeo. 2009. Relationship between Multiple Forms of Maltreatment by a Parent or Guardian and Adolescent Alcohol Use. The American Journal on Addictions 18: 226-34. [CrossRef]

Shonkoff, Jack P., W. Thomas Boyce, and Bruce S. McEwen. 2009. Neuroscience, Molecular Biology, and the Childhood Roots of Health Disparities: Building a New Framework for Health Promotion and Disease Prevention. JAMA-Journal of the American Medical Association 301: 2252-59.

Shonkoff, Jack P. 2012. Leveraging the Biology of Adversity to Address the Roots of Disparities in Health and Development. Proceedings of the National Academy of Sciences 109: 17302-17307. [CrossRef]

Skalamera, Julie, and Robert A. Hummer. 2016. Educational Attainment and the Clustering of Health-Related Behavior among U.S. Young Adults. Preventative Medicine 84: 83-89. [CrossRef]

Steele, Howard, Jordan Bate, Miriam Steele, Shanta Rishi Dube, Kerri Danskin, Hannah Knafo, Adella Nikitiades, Karen Bonuck, Paul Meissner, and Anne Murphy. 2016. Adverse Childhood Experiences, Poverty, and Parenting Stress. Canadian Journal of Behavioural Science 48: 32-38. [CrossRef]

Swanson, Jodi, Carlos Valiente, and Kathryn Lemery-Chalfant. 2012. Predicting Academic Achievement from Cumulative Home Risk: The Mediating Roles of Effortful Control, Academic Relationships, and School Avoidance. Quarterly 58: 375-408. [CrossRef]

Tietjen, Gretchen E., Jagdish Khubchandani, Nabeel A. Herial, and Kavit Shah. 2012. Adverse Childhood Experiences Are Associated with Migraine and Vascular Biomarkers. The Journal of Head and Face Pain 52: 920-29. [CrossRef] [PubMed]

Turner, Heather A., David Finkelhor, and Richard Ormrod. 2006. The Effect of Lifetime Victimization on the Mental Health of Children and Adolescents. Social Science \& Medicine 62: 13-27.

UCLA Consulting Group. n.d. How Can I Compute Indirect Effects with Imputed Data? (Method 2) I Stata FAQ. Available online: https: / / stats.idre.ucla.edu/stata/faq/how-can-i-compute-indirect-effects-with-imputed-data-method-2/ (accessed on 27 January 2020).

Wilkinson, Andra L., Carolyn Tucker Halpern, Amy H. Herring, Meghan Shanahan, Susan T. Ennett, Jon M. Hussey, and Kathleen Mullan Harris. 2016. Testing longitudinal relationships between binge drinking, marijuana use, and depressive symptoms and moderation by sex. Journal of Adolescent Health 59: 681-87. [CrossRef] [PubMed]

Wojtkiewicz, Roger A., and Mellisa Holtzman. 2011. Family structure and college graduation: Is the stepparent effect more negative than the single parent effect? Sociological Spectrum 31: 498-521. [CrossRef]

Youssef, Nagy A., Daniel Belew, Guang Hao, Xiaoling Wang, Frank A. Treiber, Michael Stefanek, Mark Yassa, Elizabeth Boswell, W. Vaughn Mccall, and Shaoyong Su. 2017. Racial/Ethnic Differences in the Association of Childhood Adversities with Depression and the Role of Resilience. Journal of Affective Disorders 208: 577-81. [CrossRef] [PubMed] 